\title{
Does the color of the collar matter? Firm specific human capital and post-displacement outcomes
}

\author{
by
}

Guido SCHWERDT, Andrea ICHINO, Oliver RUF, Rudolf WINTER-EBMER ${ }^{*}$, Josef ZWEIMÜLLER

Working Paper No. 0809

July 2008

Johannes Kepler University of Linz Department of Economics Altenberger Strasse 69 A-4040 Linz - Auhof, Austria www.econ.jku.at 


\title{
Does the color of the collar matter? Firm specific human capital and post-displacement outcomes *
}

\author{
Guido Schwerdt ${ }^{\ddagger} \quad$ Andrea Ichino ${ }^{\dagger}$ Oliver Ruf \\ Rudolf Winter-Ebmer ${ }^{\S}$ Josef Zweimüller $₫$
}

July 18, 2008

\begin{abstract}
We investigate whether the costs of job displacement differ between blue collar and white collar workers. In the short run earnings and employment losses are substantial for both groups but stronger for white collar workes. In the long run, there are only weak effects for blue collar workers but strong and persistent effects for white collars. This is consistent with the idea that firm-specific human capital and internal labor markets are more important in white-collar than in blue collar jobs.
\end{abstract}

JEL-Code: J14, J65.

Keywords: Firm Specific Human Capital, Plant Closures, Matching,

\footnotetext{
${ }^{*}$ We gratefully acknowledge financial support from the Austrian Science Foundation (FWF).

$\ddagger$ Ifo Institute for Economic Research at the University of Munich and CESifo

†University of Bologna

"University of Zurich

$\S$ University of Linz and Institute for Advanced Studies, Vienna
} 


\section{Introduction}

The loss of a job is certainly shaking up someone's career temporarily, but might also be a long-term problem for the concerned worker. To which extent does the type of a worker's job affect the costs of job displacement? Theoretical arguments suggest that losing a job associated with firm-specific human capital is more costly in terms of reduced lifetime earnings than losing a jobs where pay is closely aligned with a worker's general human capital. Similarly, workers who are displaced from a manual work, maybe with a piece rate compensation, are less likely to suffer a substantial lifetime earnings loss than workers who are displaced from their career path on internal labor markets associated with deferred payment contracts. This paper investigates this important issue by looking at displacement costs for two broad occupational groups: white collar and blue collar workers. Arguably, firm-specific human capital, internal labor markets, and career concerns are much more important in white collar than in blue collar jobs. When displacement costs are driven by loss of firm-specific rents we should observe higher displacement costs for white collar than for blue collar workers. (Lazear, 1979)

The issue has not been resolved in the empirical literature: The authors of country specific chapters in the book of Kuhn (2002) compare displacement costs across a number of countries and find no difference in terms of earnings losses across education categories. The displacement costs with respect to unemployment are mixed: In the U.S., Canada, France and Belgium, more educated workers (who are more frequently found in white collar jobs) tend to suffer less from joblessness after displacement, the reverse is true for Germany. ${ }^{1}$

We use an exceptional administrative data set, the Austrian Social Security Database (ASSD) to shed new light on the issue. This data set has three main advantages: First, it is very large and covers the universe of Austrian employees in the private sector. Second, it contains high-quality and highfrequency information on the individual workers' earnings and employment

\footnotetext{
${ }^{1}$ Podgursky and Swaim (1987) is a paper explicitly considering a white blue collar comparison: they find lower earnings losses for white collar workers using the Displaced Worker Survey.
} 
history over an extended period of time. Third, it contains an employer identifier that allows us to identify plant-closure events. Furthermore, as Austrian blue and white collar workers are subject to different social security rules (with respect to health insurance and insurance against workplace accidents) measurement error in occupational status can be ruled out.

Taking plant closures as an indicator for exogenous separations from the job we are able to identify the causal effect of displacement on worker's future careers. Our empirical strategy exploits the rich nature of our data and applies exact matching techniques which makes treatment and control groups extremely well comparable.

Our empirical findings point to large and persistent employment and earnings losses for white collar workers, but more transient and much smaller losses for blue collar workers. This is consistent with the idea that internal labor markets and firm-specific wage policies are more common among white collar workers compared to blue collars.

The paper is organized as follows. In the next section we describe the data and section 3 details our econometric strategy. Section 4 present our results and section 5 concludes.

\section{Data}

Our data set comprises the universe of private sector workers in Austria covered by the social security system. ${ }^{2}$ All employment records can be linked to firms in which workers are employed. We use quarterly information from 1978 to 1998 on daily employment and monthly earnings. This information is highly reliable, because social security tax payments for firms as well as benefits for workers hinge on these data. Monthly gross earnings are transformed in daily wages taking the ratio of earnings over effective number of employment days in each month.

We concentrate on workers employed between 1982 and 1988, who are at risk of a plant closure. ${ }^{3}$ This allows us to observe the workers' earnings and

\footnotetext{
${ }^{2}$ See Zweimüller et al. (2008) for a description of the data set.

"Workers "at risk" of a plant closure include the treatment group actually experience
} 
employment history during 4 years prior to a potential closure and for 10 years afterwards. ${ }^{4}$ We restrict the analysis to prime-age workers in the age group 35 - 50; who were employed in firms with more than 5 employees at least one quarter during the period 1982 and 1988; and workers with at one year of tenure with the current employer.

In the ASSD, each firm has an employer identifier. Exits of firms occur when the employer identifier ceases to exist. Some of these cases might not be true closures and (most of the) employees just continue under a new identifier, for example because of a takeover in a family business. To encounter this problem, we impose a further restriction: If more than $50 \%$ of the employees continue under a new employer identification number we do not consider this to be a closure. ${ }^{5}$

Our treatment group comprises 9,656 workers who experienced a plant closure between 1982 and 1988. Our control group comprises about 1 million workers from all firms not going bust during this period. To increase the comparability between treated and controls, we perform exact matching between the treated and control subjects on the following criteria: sex, age, broad occupation (blue- or white-collar), location of firm (9 provinces), industry (30 industries), employment history in the eight quarters before plant closure. ${ }^{6}$ We do almost exact matching on continuous variables: average daily wages in the quarters $8,9,10$ and 11 before plant closure are matched by decile group ${ }^{7}$ and firm size in the two years before plant closure is matched by quartile groups. Applying this matching procedure we are able to identify at least one control subject for 5,570 treated subjects, which are matched to 30,156 controls. $^{8}$

\footnotetext{
a layoff as a result of bankruptcy and the control group who does not.

${ }^{4}$ Establishments from the construction and tourism industries are excluded as temporary layoffs are common in these industries.

${ }^{5}$ Workers from such establishments are coded as "ambiguous" and are neither in the treatment nor the control group.

${ }^{6}$ See Schwerdt (2008) and Ichino et al. (2007) for a more detailed description of the matching algorithm.

${ }^{7}$ We do not want to match earnings too close to closure, because of anticipatory wage effects. See Jacobson et al. (1993) for evidence on wage effects before displacement.

${ }^{8}$ We experimented also with less restrictive matching algorithms that increase the number of matches without major quantitative changes in the results.
} 


\section{$3 \quad$ Econometric Strategy}

To estimate the effect of an involuntary job loss on future earnings and employment prospects both for blue and white collar workers we specify the following model

$$
\begin{aligned}
Y_{i, t} & =\alpha+\beta_{1,20} B L U E_{i} P C_{i} Q_{i, t}^{1,20}+\beta_{21,40} B L U E_{i} P C_{i} Q_{i, t}^{21,40} \\
& +\gamma_{1,20} B L U E_{i} Q_{i, t}^{1,20}+\gamma_{21,40} B L U E_{i} Q_{i, t}^{21,40} \\
& +\delta_{1,20} P C_{i} Q_{i, t}^{1,20}+\delta_{21,40} P C_{i} Q_{i, t}^{21,40} \\
& +\lambda_{1,20} Q_{i, t}^{1,20}+\lambda_{21,40} Q_{i, t}^{21,40}+\mu_{i}+\theta_{t}+\epsilon_{i, t}
\end{aligned}
$$

where $Y_{i, t}$ denotes the outcome variable (employment status or earnings) of individual $i$ at quarter $t, B L U E_{i}$ is a dummy variable taking the value one if individual $i$ is a blue collar worker, $P C_{i}$ is another dummy variable indicating whether individual $i$ got displaced due to a plant closure and the $Q_{i, t}$ 's are two dummy variables indicating the time period relative to plant closure (actual or potential). To keep the problem manageable and results easily interpretable, we focus on two post-displacement periods: the "short-run", defined as the first five years (twenty quarters, $Q_{i, t}^{1,20}$ ) after the displacement quarter; and the "long-run" defined as years six to ten after the plant closure quarter $\left(Q_{i, t}^{21,40}\right)$. Moreover, specification (1) includes a constant term, $\alpha$, individual fixed effects, $\mu_{i}$, calendar time effects, $\theta_{t}$ and an error term, $\epsilon_{i, t}$.

The parameters of interest in the present context are $\beta_{1,20}$ and $\beta_{21,40}$. They identify, for short- and long-run labor market outcomes respectively, whether blue collar workers suffer more $\left(\beta_{1,20}<0, \beta_{21,40}<0\right)$ or less $\left(\beta_{1,20}>0\right.$, $\left.\beta_{21,40}>0\right)$ from a plant closure than white collar workers.

\section{Results}

Figure 1 visualizes the evolution of earnings and employment by broad occupation and displacement status. Panel A shows the employment profiles for displaced (treated) and non-displaced (control) white collar workers. The graph shows mean employment rates per quarter over a period of 10 years 
- 5 years before and 10 years after a plant closure. By construction, the employment rates of displaced and non-displaced white collar workers are equal to unity in the four quarters prior to the plant closure date (all workers have at least one year of tenure). Employment rates at earlier dates show that our matching procedure works well: During quarters -16 to -5 (quarters prior to plant closure) employment rates of treated and controls are identical. Immediately after the plant closure employment rates for the treated white collar workers decrease sharply. Only about 50 percent find a new job during the first quarter after displacement. Employment rates of displaced white collar workers catch up during the first two years and decrease thereafter but never reach the level of the non-displaced. (Notice that employment rates of the non-displaced decrease smoothly after the plant closure quarter. This reflects dissolution of employment relationships that existed at the sampling date as workers got either unemployed, sick, retired, died, or dropped out of the labor force for other reasons.)

Panel B shows the corresponding picture for blue collar workers. The immediate loss in employment after plant closure is somewhat higher for displaced blue collar workers. However, displaced blue collar workers recover much faster and, about 6 years after the plant closure quarter, reach a level that is only slightly below the employment rates of non-displaced blue collars. In sum, the graphical analysis shows that employment losses of displaced white collar workers are permanent and very strong. In contrast, employment losses for displaced blue collar workers are of a more temporary nature and small in the long run.

Panels $\mathrm{C}$ and D portray the analogous phenomenon for the evolution of workers' earnings. The numbers show mean nominal daily earnings, conditional on being employed. Obviously, this measure changes over time due to increases in real earnings, in inflation and in selectivity (because the set of employed workers changes over time). Just like in panels A and B, we see a remarkable difference between white and blue collar workers. Daily wages for displaced blue collar workers are only slightly below daily wages of non-displaced blue collars throughout the post-plant closure period. In contrast, the earnings profile of displaced white collar workers is substantially 
below the one of their non-displaced colleagues and remains at this lower level throughout the post-plant closure period.

Table 1 presents regression results from estimating equation (1), both for employment and for daily wages. The coefficients in column (1) are estimated from a linear probability model with the individual's employment status as a dependent variable and the coefficients in column (2) are from a regression with the daily wage as the dependent variable. Both regressions include individual fixed effects and dummies for calendar months.

Column (1) reveals that displaced white collar workers face substantial employment losses equal to a .231 reduction in the employment probability (coefficient of $P C_{i} Q_{i, t}^{1,20}$ ) in the short run (years 1 to 5 after displacement) and a .137 reduction $\left(P C_{i} Q_{i, t}^{21,40}\right)$ in the long run (years 6 to 10 after displacement). Displacement effects for blue collar workers are much more moderate and amount to a decrease in the employment probability of .149 (-.231+ .082) in the first five post-displacement years and a corresponding decrease of .046 (-.137 + .091) in post-displacement years 6 to 10 .

The blue-white collar differences in earnings losses are even more striking. Column (2) shows that earnings losses for displaced white collar are large both in the short-run (-.079 log points, coefficient of $\left.P C_{i} Q_{i, t}^{1,20}\right)$ and in the long-run (-.078 log points, $\left.P C_{i} Q_{i, t}^{21,40}\right)$. In contrast, blue collar workers' earnings drop by only .023 log-points $(-.079+.056)$ in the short-run and by negligible .006 log-points $(-.078+.072)$ in the long-run.

\section{Conclusion}

This paper investigates whether the costs of being displaced from a job differs by the blue- or white-collar nature the job. Our findings suggest that both white collar and blue collar workers experience a decrease in employment rates and earnings in the short run (during the first five years after a plant closure). However, for white collar workers these detrimental short-run effects are much stronger. Moreover, for blue collar workers employment losses are modest and earnings reductions are negligible in the long run (during years 6 to 10 after a plant-closure event). In contrast, white collar workers experience 
strongly negative employment and earnings effects also in the long run.

Arguably, in white collar jobs career concerns, firm-specific human capital, and internal labor markets are more important than in blue collar jobs. Blue collar workers do mostly manual work and are frequently paid piece rates. Hence our results are consistent with the idea that displacement costs are higher for workers displaced from jobs associated with more job-specific rents. Individuals who lose such jobs are confronted with a worse position on the labor market and experience a major disruption of their career path not only temporarily but also in the long run. 


\section{References}

Ichino, A., Schwerdt, G., Winter-Ebmer, R., and Zweimüller, J. (2007). Too old to work, too old to retire? CESifo Working Paper No. 2118.

Jacobson, L. S., LaLonde, R. J., and Sullivan, D. G. (1993). Earnings losses of displaced workers. American Economic Review, 83(4):685-709.

Kuhn, P., editor (2002). Losing Work, Moving On: Worker Displacement in International Perspective. Kalamazoo, Mich.

Lazear, E. (1979). Why is there mandatory retirement? Journal of Political Economy, 87(6):1261-1284.

Podgursky, M. and Swaim, P. (1987). Job displacement and earnings loss: evidence from the displaced worker survey. Industrial and Labor Relations Review, 41(1):17-29.

Schwerdt, G. (2008). Labor turnover before plant closure: leaving the sinking ship vs. captain throwing ballast overboard. CESifo Working Paper 2252.

Zweimüller, J., Winter-Ebmer, R., Lalive, R., Kuhn, A., Oliver, R., and Wuellrich, J.-P. (2008). The austrian social security database (assd). IEW Working Paper, University of Zurich. 


\section{Tables \& Figures}

Table 1: Estimation results

\begin{tabular}{lcc} 
& Employment & Earnings \\
\cline { 2 - 3 } & $(1)$ & $(2)$ \\
\hline $\mathrm{BLUE}^{*} \mathrm{PC}^{*} Q_{01,20}$ & .082 & .056 \\
$\mathrm{BLUE}^{*} \mathrm{PC}^{*} Q_{21,40}$ & $(.01)^{* *}$ & $(.01)^{* *}$ \\
& .091 & .072 \\
$\mathrm{PC}^{*} Q_{01,20}$ & $(.014)^{* *}$ & $(.012)^{* *}$ \\
$\mathrm{PC}^{*} Q_{21,40}$ & -.231 & -.079 \\
& $(.006)^{* *}$ & $(.007)^{* *}$ \\
$\mathrm{BLUE}^{*} Q_{01,20}$ & -.137 & -.078 \\
& $(.008)^{* *}$ & $(.008)^{* *}$ \\
$\mathrm{BLUE}{ }^{*} Q_{21,40}$ & -.019 & -.031 \\
& $(.004)^{* *}$ & $(.004)^{* *}$ \\
$Q_{01,20}$ & -.056 & -.041 \\
$Q_{21,40}$ & $(.008)^{* *}$ & $(.006)^{* *}$ \\
Const. & -.033 & .023 \\
Obs. & $(.003)^{* *}$ & $(.003)^{* *}$ \\
$R^{2}$ & -.12 & .027 \\
$F$ statistic & $(.005)^{* *}$ & $(.004)^{* *}$ \\
\hline \hline
\end{tabular}

${ }^{*}$ All regressions include individual fixed effects and dummies for calendar time. Dependent variables are an employment dummy in column 1 and log daily earnings in column 2. Clustered standard errors reported in parenthesis. 
Figure 1: Employment and Earnings
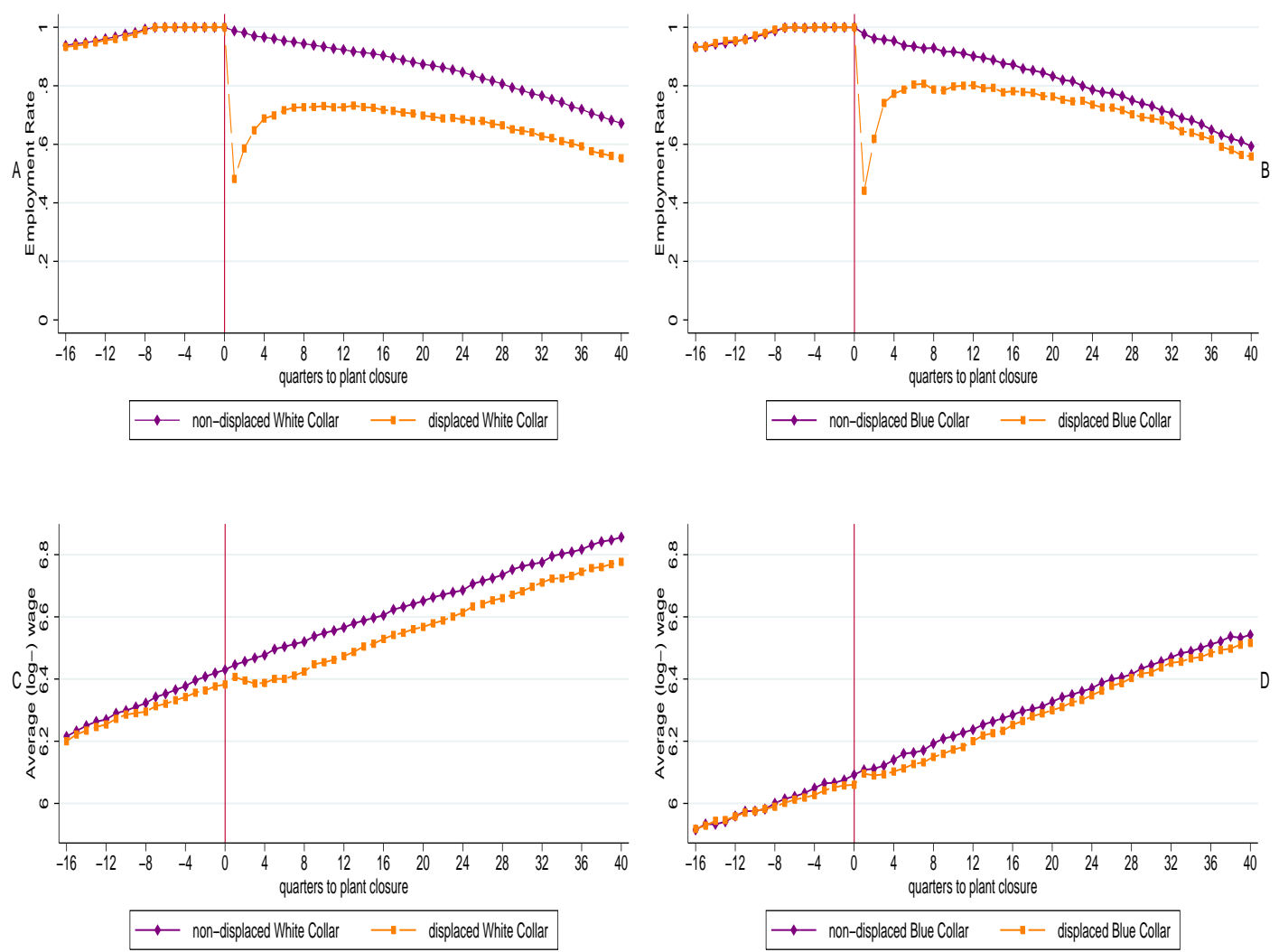